\title{
Background Characteristics of Board Secretary and IPO Underpricing
}

\author{
Zhihao Lin \\ School of Management, Jinan University, Guangzhou, China \\ Email: swlzh1226@163.com
}

How to cite this paper: Lin, Z.H. (2017) Background Characteristics of Board Secretary and IPO Underpricing. Modern Economy, 8, 1340-1356.

https://doi.org/10.4236/me.2017.811090

Received: October 24, 2017

Accepted: November 21, 2017

Published: November 24, 2017

Copyright $\odot 2017$ by author and Scientific Research Publishing Inc. This work is licensed under the Creative Commons Attribution International License (CC BY 4.0).

http://creativecommons.org/licenses/by/4.0/

\section{c) (i) Open Access}

\begin{abstract}
The information asymmetry between the internal environment and external environment of enterprises composes one of essential factors leading to IPO underpricing. According to upper echelon theory, background characteristics of senior executives will exert an impact on their behaviors selections as well as the performance of company. The board secretary in China, as the information publisher, can also influence IPO underpricing with his/her personal background. Testing the samples of GEM (The Growth Enterprise Market) in China from the year of 2009 to 2012, the paper concluded that the board secretary with financial background and related working experience can reduce the IPO underpricing, based on which the conclusion has been drawn that the personal background characteristics can influence IPO underpricing and further affect the IPO pricing efficiency, hoping to provide reference for enterprises to recruit the right person for board secretary.
\end{abstract}

\section{Keywords}

Board Secretary, IPO Underpricing, Information Asymmetry

\section{Introduction}

IPO (Initial Public Offerings) is the process of the first time the limited company or enterprise sold shares to the public. Due to the existence of asymmetric information between the issuing company and external investors, it tends to be difficult for the investors outsides to make a proper price to new issue. IPO underpricing refers to the phenomenon that the first-day market closing price is much higher than the issuing price.

Two primary functions of board secretary in enterprises that serve as the necessary participant in enterprises' IPO procedure, as have been written in stock listing rules, are to coordinate the relationship between investors and reveal in- 
formation of the company. Companies, especially IPO-bound companies, require board secretaries to standardize the company's operation, organize meetings, coordinate with intermediary agencies and conduct information disclosure towards the external world, from which it can be seen the board secretary is playing a vital role as a "bridge" linking the company with the external world. And personalities of board secretary will definitely exert influence on his/her performance in career. Different board secretaries have different personal characteristics, including their professional backgrounds, working experience, terms of office, age, gender and so on. In "upper echelons theory" proposed by Hambrick and Mason in 1984 [1], background characteristics variables including academic qualification, gender, terms of office, working experiences and so on have been taken as alternative variables representing characteristics of senior executives' mentality, to research these variables' influences on senior executives' behavior selection, company's performances and so on. In previous works, scholars have conduct researches on the influences of board secretaries' involving other works (Gao Qiang \& Wu Lina, 2008; Mao Xinshu et al., 2013) [2] [3], holding shares (Zhou Kaiguo, 2011; Zhai Guangyu et al., 2014) [4] [5], possessing social capitals (Gao Fenglian \& Wang Zhiqiang, 2013) [6], gender (Lin Changquan et al., 2016) [7] on the quality of their information disclosure. The study of board secretaries' personal characteristics' impact on other aspects of the enterprises remains lack, especially impact on IPO of enterprises, of which the board secretaries play an irreplaceable role in procedure to price new issue.

China adopts IPO pricing inquiry system for IPO, say, both the issuing companies and underwriters determines the issuing price of new shares by inquiries at institutional investors, which mainly consists of "initial inquiring price" and "accumulative bidding inquiring price": "initial inquiring price" refers to that the issuing companies and underwriters inquire to the inquiry recipients and determine the interval of issuing price of new shares and scope of P/E ratio based on the inquiry results; while "accumulative bidding inquiring price" refers to that, when the number of investors' effective applications is greater than that of new issue but the over-subscription rate is less than 5 times, then the issuing price would be lower threshold of the inquiry; and the rate is greater than 5 times, then downward accumulative computation should be conducted tick-by tick starting from the effective application with the highest price till the oversubscription rate exceeds 5 times for the first time, and then set the price got as the issuing price. During the IPO initial inquiring price, to determine the price, institutional investors need to evaluate the company by combining all information of IPO-bound companies, including prospectus, information company published on road show, media's report on the issuing companies (during the listing process, board secretaries are supposed to take initiate to constantly confirm the accuracy of media's reports) and so on, to make the proper price. Meanwhile, board secretaries are also required to coordinate the relations of the company with the investors, deal with investors' visiting, provide consultations and related information about the company for the investors. The personnel in the enter- 
prises have more information about the company, thus, they would have a more efficient and accurate understanding of real value, development perspective, potential risks and so on.

Thus, the information asymmetry between the internal and the external become quite obvious. The degree of information asymmetry is influenced by the quality of information disclosure [8], and composes one reason leading to IPO underpricing. In Winner's Curse Hypothesis proposed by Rock in 1986 [9], to attract more unknown investors to participate in the subscription of new shares, the company would issue cheap shares to make up the loss of the unknowns caused by information asymmetry, which has also been proved by Beatty and Ritter in 1986 [10]. Therefore, the ability of the board secretaries to handle the information disclosure will influence the information asymmetry between the internal and the external environment of the enterprises thus influences the offer the investors set.

So, is there any relation between personal characteristics of board secretaries and IPO underpricing? And if there is, then how does a personal characteristic of board secretaries exert impact on IPO underpricing? To find the answers, the paper selects companies listed on GEM (The Growth Enterprise Market) in China from the year of 2009 to 2012 as the samples to conduct the researches. ${ }^{1}$

Major contributions of this paper has been listed as following: for the first of all, board secretaries received too little attention from academic circle, and literature available about board secretary all focus on its role to disclose information. IPO, as a significant financing way of company, especially the typical topic, IPO underpricing, has attracted many attentions from academic circle. However, there is rare research on relations between background of board secretaries and IPO underpricing. Secondly, influence of board secretaries on IPO goes without saying, resulting a series of phenomena like companies compete for board secretaries with rich experiences and board secretaries get a large amount of equity incentives, which have been discussed widely on market. Through empirical test, the paper attempted to provide some empirical evidences presenting the influence of board secretaries on IPO.

In upper echelon theory, Hambrick and Mason took background characteristics variables including academic degree, gender, age, office terms, working experiences and so on as alternative variables of characteristics of senior executives' mentality to study these factors' effects on the behavior selection of senior executives and performance of companies [1]. Meanwhile, professional knowledge and experiences also serve as necessary foundation for secretaries to make effective professional decisions [11]. If senior executives possess certain professional knowledge in some aspects and selectively choose their job, they will be able to more accurately understand the relevant information and make more appropriate decisions [12] [13]. As the "bridge" linking the capital market and issuing companies, board secretaries play a vital role in information disclosure

${ }^{1}$ The paper only selects data from 2009 to 2012 , because IPO has been suspended in A-share marker in 2013, and the maximum of the first-day jump of new share in 2014 and beyond has reached up to $44 \%$. 
and maintenance of relations of companies with investors. The board secretary with financial background will have high level of financial knowledge, with which he/she can more effectively publish information thus to reduce the information asymmetry between the internal and the external environment of the enterprises [14]. In capital market driven by information, quality of information disclosed by the companies will have an effect on the degree of information asymmetry. Due to the existence of information asymmetry between the issuing and the investors, investors cannot get the real value of the company. If board secretaries have relative background knowledge, he/she can be a more appropriate communicator in capital market to provide more effective explanation and information disclosure thus to improve the quality of information disclosure [15], the higher quality of information of IPO-bounce the investors get, the lower the information asymmetry is, the closer investors' evaluation of company's value to the real value, the smaller the IPO underpricing rate. Thus, hypothesis 1 can be proposed as following:

H1: Board secretary with financial background can increase IPO underpricing rate.

Previous studies have showed that previous working experiences of senior executives will exert an influence on enterprises' policy making. Board secretaries with working experience in investment banks can contribute to companies' M \& A [16]; financial experience as directors in state-holding enterprises will make them emphasize more on the profit, leading to higher possibility of over-investment [17]; senior executive with CPA working skills and experiences can improve the earnings management of accruals [18]. Board secretaries with working experiences in other companies will have better understanding about IPO procedure and relative requirements in laws and regulations related to information disclosure and appear to be more sensitive to relative policies. Meanwhile, with rich experiences communicating with intermediary and supervision agencies, these board secretaries will be more proficient in managing the relations with these agencies. These "professional board secretaries" are more familiar with requirements of supervision department on information disclosure [19]. Additionally, board secretaries will obtain more experiences and stronger professional skills during their job-hopping [20]. It is these previous experiences that allows these board secretaries to be more sensitive to information disclosed and disclose information more accurately and effectively thus to reduce the information asymmetry. Therefore, hypothesis 2 can be proposed as following:

H2: Board secretaries with working experiences as board secretary can decrease IPO underpricing rate.

\section{Literature Review}

\subsection{Research Related to Board Secretaries}

Board secretaries are required to coordinate the relationship with the investors and timely accurately disclose the company's information at the same time, both 
of which have been studied by many scholars. For example, good investor relations management can effectively improve company's performance [21]; the board secretaries who also serve as assistant general managers can improve the quality of information disclosure [2] [3], and when the board secretaries hold the shares of the company, the quality of information disclosure will be declined [4]. But in banking, due to factors including long office term of board secretaries and small-scale of urban banks, quality of information disclosure tends to be improved with board secretaries holding the share [5]. Jiang Fuxiu et al. (2016) has found that enterprises employing board secretaries with financial experiences enjoy lower financing constraints and higher level of enterprises' earning information; the stronger the financial professional ability or the higher the academic level of the board secretaries are, the greater influence they will have on the enterprises [14] [22]. Wu Yuhui, Wu Shinong et al. [19] defined board secretaries with financial or related working experiences as the professionals that can boost the success rate and accelerate IPO procedure.

Furthermore, social capital also composes an important part of personal characteristics of board secretaries. Based on social capital embeddedness theory, Gao Fenglian and Wang Zhiqiang (2015) to construct index system from perspective of horizontal point, vertical point and social reputation, finding that the larger the social capital the board secretaries hold, the higher the information disclosure will be; besides, positive effect of board secretaries' social capital on quality of information disclosure in regions with poorer legal protection appears to be more significant [6].

\subsection{Research Related to IPO Underpricing}

Since Ibbotson found in 1975 that the existence of $11.4 \%$ abnormal returns in the first day of American 120 new shares issue, IPO underpricing has always been a vibrant issue discussed in financial field [23]. In "Winner Curse" proposed by Rock in 1986 [9], to attract unknown investors to participate in subscription, the company will issue cheap shares to make up the losses of the unknown caused by information asymmetry; Measuring the information asymmetry by "ex ante uncertainty", Beatty and Ritter (1986) concluded that there should be positive correlation between the RIPO and ex ante uncertainty [10]. RIPO of smaller companies will be relatively higher due to their greater uncertainty that would lead to more risks. Besides, the researchers further proved Rock's "Winner Curse" by measuring the degree of uncertainty in accordance with other variables; in "Market Climate Hypothesis" proposed by Ritter in 1984 [24], it was thought that the stock price risk will be higher in a bull market, leading to increasing of prior uncertainty, making it more difficult for investors to evaluate the value of the issuing companies, thus, it will contribute to attracting more investors if issuing companies and underwriters have the degree of IPO underpricing enlarged; Leone, Rock and Willenborg found in 2007 that IPO underpricing will be reduced if companies are volunteer to disclose the use of 
funds, because that would reduce the information asymmetry between the company and external investors [25].

China, one of emerging markets countries, present higher IPO underpricing rate compared with European countries and America while facing complex economic environment. In terms of institutions, Chen Gongmeng and Gao Ning (2000) that Chinese adopting price-earnings ratio method for stock price may lead to lower price of new issues [26]; in 2005, Jing Chi and Carol Padgett found that Chinese IPO underpricing rate has reached up to $129.16 \%$, which, from their perspective, is primarily caused by quota system and the existence of a great number of "uninformed investors" [27]; it is the unbalanced market that caused high IPO underpricing rate, and that it is government's regulation on new issue that lead to IPO underpricing. After China Securities Regulatory Commission (CSRC) canceled the limitation on price of new issues, IPO pricing efficiency increases and underpricing rate decreases, but this was accompanied by medium and small investors' suffering from "Winner Curse" [28]. In 2014, Weng Xiaowei found that families' participating in management of enterprises can more effectively solve the managerial agency problems between the shareholders and managers and deliver the value of enterprises to the market to reduce the information asymmetry between internal and external environment of enterprises thus to reduce the IPO underpricing rate [29]; in 2016, Xu Xin at al. found that uncertain $\mathrm{R} \& \mathrm{D}$ expenditure hard to evaluate will enlarge the information asymmetry, then have the IPO underpricing increased; when disclosing their profitable patents and classified technology, companies can deliver positive signal to the market and ease the uncertainty of $\mathrm{R} \& \mathrm{D}$ expenditure and information asymmetry, thus to reduce IPO underpricing [30].

From literature reviews above, it can be told that most previous researches were focusing on board secretaries' role in influencing the quality of information disclosure and management of relations with investors, without much attention to their essential function as "bridge" in IPO procedure. China has a unique stock market, with an operating system different from other western developed countries. Among researches on IPO underpricing, the major has been concentrated on the solutions to new issuance, underwriters' reputations, auditors' reputations and information asymmetry, without much attention to the effect of personal background characteristics of the board secretary as the information publisher, on IPO underpricing.

\section{Research Design}

\subsection{Sample Selection and Data Sources}

Being different from those on main boarding listing, companies listed on GEM in China are featured by high growth and small scale, and they are younger and present higher operation risks, thus, information asymmetry of GEM listed companies appear to be higher. The amount of IPO underpricing of issuing companies listed on GEM in China from 2009 to 2012 reached up to 69.9176 bil- 
lion, 4.3 times the amount of the issuing. This was a great loss of IPO-bound companies. (Xu Xin et al., 2016) The paper selects 352 IPO data of companies listed on GEM in China from 2009 to 2012, after screening out companies with information defaults or those listed without pricing inquiring [30]. Financial backgrounds of board secretaries, whether they have experiences working as board secretary, were all collected manually from Hexun, Cninfo, Sina Finance. Enterprises' IPO data come from CSMAR database; data missed were restored manually by Hexun; ranking of accounting firms were gathered from official website of AICPA; software used in the research is Stata 11.0. $1 \%$ and $99 \%$ winsorize processing were conducted on continuous variables. Table 1 presents some sample data and main variables.

\subsection{Model Setup and Variable Definition}

In model 1, when the board secretaries have financial background, finance equals to 1 , otherwise, finance equals to 0 . In this paper, following several kinds of board secretaries would be regarded as board secretaries with financial background: board secretaries that major in finance, economy, accounting, possess financial and economics qualification (like CPA, CFA, ACCA and so on), have working experiences related to finance (for example, experience serving as CFO, chief accountant, securities affairs representative, securities trader or other working experiences in accounting firm).

In model 2, if the board secretary has experience serving as board secretary in other company, then experienced equals to 1 , otherwise, it equals to 0 . According to Ritter and Well [31], in most researches, IPO underpricing has been defined as the ratio of the excess of first-day closing-price over the issuing price to the issuing price, say, underpricing $=\left(\mathrm{P}-\mathrm{P}_{0}\right) / \mathrm{P}_{0}$, in which, $\mathrm{P}$ represents closing price on first day, $\mathrm{P}_{0}$ represents the issuing price.

$$
\begin{gathered}
\text { underpricing }=\beta_{0}+\beta_{1} \text { finance }+\beta_{i} \sum \text { Control }_{i}+\varepsilon \\
\text { underpricing }=\beta_{0}+\beta_{1} \text { experienced }+\beta_{i} \sum \text { Control }_{i}+\varepsilon
\end{gathered}
$$

The regression analysis to underpricing use the experience of other scholars, such as Weng Xiaowei, Chen Gongmeng. And the function of the two models is to verify, by regression analysis, whether the background of board secretaries would exert an impact on IPO underpricing rate. Model 1 is to verify whether the financial background of board secretaries would exert an impact on IPO underpricing rate; model 2 is to see whether the experience serving as the board secretary would have an impact on IPO underpricing rate.

Based on previous researches, following variables as following are also controlled in the model: the age, academic qualification, salary, increase rate of business revenue, company's founding time, time interval between issue date and launch date, allocation rate, debt ratio, scale of company, IPO pricing, return on equity, the proportion of independent directors, market return, reputation of accountant firm, industry, year. Specific definition of all variables has been listed in variable definition Table 2. 
Table 1. Some sample data and main variables.

\begin{tabular}{|c|c|c|c|c|c|c|c|c|}
\hline Compay code & underpricing & finance & experienced & edu & lag_number & subscription & estyear & iposize \\
\hline 300001 & 0.8487 & 1 & 0 & 0 & 2.5649 & 0.8114 & 0.0794 & 4.2047 \\
\hline 300002 & 0.7741 & 1 & 0 & 1 & 2.5649 & 1.2249 & 0.0794 & 4.6151 \\
\hline 300003 & 1.1862 & 0 & 0 & 0 & 2.5649 & 0.7590 & 0.0794 & 4.8203 \\
\hline 300004 & 0.7584 & 1 & 0 & 0 & 2.5649 & 1.1772 & 0.0794 & 4.8283 \\
\hline 300005 & 1.4044 & 1 & 0 & 1 & 2.5649 & 0.5377 & 0.0794 & 4.8598 \\
\hline 300006 & 1.1697 & 1 & 0 & 1 & 2.5649 & 0.4960 & 0.0794 & 4.7958 \\
\hline 300007 & 0.8041 & 1 & 0 & 1 & 2.5649 & 1.0199 & 0.0794 & 3.9703 \\
\hline 300008 & 0.8277 & 1 & 0 & 0 & 2.5649 & 0.7347 & 0.0794 & 4.5644 \\
\hline 300010 & 0.8750 & 0 & 0 & 0 & 2.5649 & 0.6532 & 0.0794 & 4.8598 \\
\hline 300011 & 0.8651 & 1 & 0 & 0 & 2.5649 & 1.1006 & 0.0404 & 4.4773 \\
\hline 300012 & 0.7797 & 1 & 0 & 1 & 2.5649 & 1.2582 & 0.0404 & 4.2485 \\
\hline 300013 & 1.0641 & 1 & 0 & 0 & 2.5649 & 0.7505 & 0.0404 & 5.0239 \\
\hline 300014 & 1.4044 & 0 & 0 & 0 & 2.5649 & 0.7000 & 0.0404 & 4.5433 \\
\hline 300015 & 0.8536 & 1 & 0 & 0 & 2.5649 & 0.8877 & 0.0404 & 4.3945 \\
\hline 300016 & 0.9933 & 0 & 0 & 1 & 2.5649 & 0.7744 & 0.0404 & 5.3230 \\
\hline 300017 & 0.8708 & 1 & 0 & 0 & 2.5649 & 0.9707 & 0.0404 & 4.7622 \\
\hline 300018 & 0.7620 & 0 & 0 & 1 & 2.5649 & 1.1459 & 0.0404 & 4.5539 \\
\hline 300019 & 0.9687 & 0 & 0 & 0 & 2.5649 & 0.6925 & 0.0404 & 4.8828 \\
\hline 300020 & 0.8200 & 0 & 0 & 0 & 2.5649 & 0.5867 & 0.0283 & 5.3132 \\
\hline 300021 & 1.2879 & 1 & 0 & 0 & 2.5649 & 0.4896 & 0.0283 & 4.0431 \\
\hline 300022 & 0.9893 & 1 & 0 & 1 & 2.5649 & 0.9392 & 0.0283 & 5.1818 \\
\hline 300023 & 0.8408 & 1 & 0 & 0 & 2.5649 & 0.9195 & 0.0283 & 4.6250 \\
\hline 300024 & 0.8882 & 1 & 0 & 1 & 2.5649 & 0.8230 & 0.0283 & 4.7362 \\
\hline 300025 & 1.2889 & 1 & 0 & 1 & 2.5649 & 0.5252 & 0.0283 & 4.3307 \\
\hline 300026 & 0.7750 & 1 & 0 & 0 & 2.5649 & 1.0121 & 0.0283 & 5.0563 \\
\hline 300027 & 1.4044 & 1 & 0 & 1 & 2.5649 & 0.6136 & 0.0283 & 4.0775 \\
\hline 300029 & 0.4846 & 0 & 0 & 1 & 2.4849 & 0.3986 & -0.0280 & 4.5539 \\
\hline 300030 & 0.3596 & 1 & 1 & 1 & 2.4849 & 0.5255 & -0.0280 & 5.0752 \\
\hline 300031 & 0.5145 & 1 & 0 & 0 & 2.4849 & 0.5650 & -0.0280 & 4.6728 \\
\hline 300032 & 0.4789 & 1 & 0 & 1 & 2.4849 & 0.5897 & -0.0280 & 5.2627 \\
\hline 300033 & 0.3330 & 0 & 0 & 1 & 2.4849 & 0.6904 & -0.0280 & 4.6052 \\
\hline 300034 & 0.4613 & 1 & 0 & 1 & 2.4849 & 0.4567 & -0.0280 & 4.4427 \\
\hline 300035 & 0.3417 & 0 & 0 & 0 & 2.4849 & 0.4807 & -0.0280 & 4.2195 \\
\hline 300036 & 0.6429 & 0 & 0 & 1 & 2.4849 & 0.3141 & -0.0280 & 5.0106 \\
\hline 300037 & 0.4488 & 0 & 0 & 1 & 3.3673 & 0.8203 & 0.0188 & 4.5433 \\
\hline 300038 & 0.3846 & 1 & 0 & 1 & 3.3673 & 0.5606 & 0.0188 & 4.1431 \\
\hline 300039 & 0.1968 & 1 & 0 & 0 & 3.3673 & 0.7971 & 0.0188 & 4.7536 \\
\hline
\end{tabular}


Z. H. Lin

\begin{tabular}{|c|c|c|c|c|c|c|c|c|}
\hline 300040 & 0.2691 & 1 & 1 & 1 & 3.3673 & 0.6200 & 0.0188 & 4.7274 \\
\hline 300041 & 0.2745 & 0 & 0 & 0 & 3.3673 & 0.8638 & 0.0188 & 4.9127 \\
\hline 300042 & 0.3449 & 0 & 0 & 0 & 3.3673 & 0.6468 & 0.0188 & 4.8442 \\
\hline 300043 & 0.1373 & 1 & 0 & 1 & 3.3673 & 0.9180 & 0.0098 & 4.7449 \\
\hline 300044 & 0.2909 & 1 & 0 & 1 & 3.3673 & 0.3728 & 0.0098 & 5.0370 \\
\hline 300045 & 0.2700 & 1 & 1 & 1 & 3.3673 & 0.6650 & 0.0098 & 4.6347 \\
\hline 300046 & 0.2337 & 1 & 1 & 0 & 3.3673 & 0.7146 & 0.0098 & 4.2767 \\
\hline 300047 & 0.1757 & 0 & 0 & 0 & 3.3673 & 0.5747 & 0.0098 & 5.3181 \\
\hline 300048 & 0.2377 & 1 & 0 & 1 & 3.3673 & 0.7317 & 0.0098 & 4.3695 \\
\hline 300049 & 0.1832 & 1 & 0 & 0 & 3.3673 & 0.6238 & 0.0098 & 4.5644 \\
\hline 300050 & 0.3094 & 1 & 0 & 1 & 3.3673 & 1.3540 & 0.0098 & 4.5951 \\
\hline 300051 & 0.1003 & 1 & 1 & 1 & 3.6376 & 0.6032 & 0.0205 & 4.2905 \\
\hline
\end{tabular}

Data source: The variables of finance and experienced are from Hexun, Cninfo, Sina Finance ${ }^{2}$; Enterprises' IPO data are from CSMAR database.

Table 2. Definition of variables.

\begin{tabular}{|c|c|}
\hline Name of variable & Description and calculation of variables \\
\hline lnage & Logarithm of board secretary's age \\
\hline edu & $\begin{array}{l}\text { Equals to } 1 \text { for secretaries with master degree or beyond, } \\
\text { and equals to } 0 \text { for the rest }\end{array}$ \\
\hline lnwage & Logarithm of board secretary's yearly salary \\
\hline growth & $\begin{array}{c}\text { The average main business revenue growth in last three } \\
\text { years before IPO }\end{array}$ \\
\hline estyear & $\begin{array}{l}\text { Listing service life }=\ln \text { (length between time to market } \\
\text { and founding time of the company) }\end{array}$ \\
\hline lag & Logarithm of time interval between issuing date and launch date \\
\hline subscription & Subscription rate of online issuance \\
\hline debt & Asset-liability ratio at the end of year before IPO \\
\hline size & $\begin{array}{c}\text { Company's size, logarithm of company's general assets } \\
\text { at the end of year before IPO }\end{array}$ \\
\hline IPO size & IPO size $=$ In (number of share in issue ${ }^{*}$ issue price) \\
\hline ROA & ROA at the end of year before IPO = net margin/total assets \\
\hline independ director & Proportion of independent directors \\
\hline cpa firm rank & $\begin{array}{l}\text { Equals to } 1 \text { for companies employing top ten } \\
\text { accounting firm; equals to } 0 \text { for the rest }\end{array}$ \\
\hline market return & Market return on the day of IP \\
\hline Industry & Industry Dummy \\
\hline Year & Year Dummy \\
\hline
\end{tabular}

\section{Empirical Results and Analysis}

\subsection{Descriptive Statistics}

Descriptive statistics of all variables have been shown in Table 3. The mean,

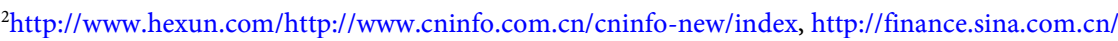


Table 3. Descriptive statistics of variables.

\begin{tabular}{|c|c|c|c|c|c|c|c|c|}
\hline Variables & $\mathbf{N}$ & Mean & SD & Q1 & Med & Q3 & Min & $\operatorname{Max}$ \\
\hline underpricing & 352 & 0.330 & 0.341 & 0.081 & 0.245 & 0.514 & -0.142 & 1.519 \\
\hline finance & 352 & 0.724 & 0.447 & 0.000 & 1.000 & 1.000 & 0.000 & 1.000 \\
\hline experienced & 352 & 0.114 & 0.318 & 0.000 & 0.000 & 0.000 & 0.000 & 1.000 \\
\hline gender & 352 & 0.722 & 0.449 & 0.000 & 1.000 & 1.000 & 0.000 & 1.000 \\
\hline edu & 352 & 0.426 & 0.495 & 0.000 & 0.000 & 1.000 & 0.000 & 1.000 \\
\hline lnage & 352 & 3.689 & 0.165 & 3.569 & 3.701 & 3.784 & 3.258 & 4.159 \\
\hline lnwage & 352 & 11.920 & 0.620 & 11.513 & 11.887 & 12.281 & 10.612 & 13.677 \\
\hline lag_number & 352 & 3.160 & 0.346 & 2.996 & 3.258 & 3.401 & 2.398 & 3.638 \\
\hline market return & 352 & 0.002 & 0.043 & -0.029 & 0.002 & 0.028 & -0.100 & 0.106 \\
\hline subscription & 352 & 1.163 & 1.129 & 0.553 & 0.800 & 1.259 & 0.290 & 7.164 \\
\hline lag & 352 & 2.494 & 0.295 & 2.303 & 2.398 & 2.639 & 2.197 & 3.584 \\
\hline IPO size & 352 & 10.929 & 0.540 & 10.550 & 10.870 & 11.272 & 9.846 & 12.332 \\
\hline estyear & 352 & 4.743 & 0.346 & 4.500 & 4.741 & 4.956 & 3.970 & 5.455 \\
\hline debt & 352 & 0.375 & 0.160 & 0.261 & 0.377 & 0.509 & 0.045 & 0.735 \\
\hline size & 352 & 19.593 & 0.581 & 19.180 & 19.545 & 19.979 & 18.533 & 21.488 \\
\hline Independ director & 352 & 0.370 & 0.051 & 0.333 & 0.333 & 0.429 & 0.333 & 0.600 \\
\hline growth & 352 & 0.496 & 0.495 & 0.253 & 0.377 & 0.585 & -0.060 & 3.569 \\
\hline ROA & 352 & 0.180 & 0.076 & 0.127 & 0.165 & 0.216 & 0.067 & 0.433 \\
\hline cpa firm rank & 352 & 0.313 & 0.464 & 0.000 & 0.000 & 1.000 & 0.000 & 1.000 \\
\hline
\end{tabular}

median, minimum and maximum of underpricing equals to $0.330,0.245,-0.142$ and 1.159, respectively, suggesting IPO underpricing is a common phenomenon in Chinese GEM market with a relatively high IPO underpricing rate. The mean of finance equals to 0.724 , suggesting $72.4 \%$ percent of board secretaries have financial background. As shown in Table 3, the ration of the number of board secretaries with financial background and that of those without financial background is much greater than 1 , and remain steady. The mean of experienced is 0.114 , suggesting only $11.4 \%$ of board secretaries have experience working as board secretaries in other company. The mean of gender is 0.722 , suggesting that $72.2 \%$ of board secretaries are men. The mean of edu is 0.426 , suggesting $42.6 \%$ of board secretaries have master degree or higher academic qualification; the mean, median and standard deviation of lnage are 3.689, 3.701 and 0.165, respectively, among which, the mean is quite close to the median, presenting equal age distribution with small distribution among board secretaries. The mean, median, standard deviation of lnwage are $11.920,11.887$ and 0.620 respectively, in which the mean is quite close to the median, suggesting that the wages of board secretaries are distributed equally, with small fluctuation. The mean and standard deviation of estyeat, debt, proportion of independent director, growth, ROA, cpa firm rank, are 4.743 and $0.346,0.375$ and $0.160,0.370$ and $0.051,0.496$ 
and $0.495,0.180$ and $0.076,0.313$ and 0.464 respectively, suggesting that $31.3 \%$ of GEM IPO companies chose top 20 accounting firms.

\subsection{Empirical Result}

Regression analysis result of relations between board secretaries' financial background and IPO underpricing rate has been illustrated in Table 4. In model (1), the coefficient of experienced equals to -0.0670 and presents negative significant relations on level of $5 \%$, which suggests that board secretaries with financial background can decrease IPO underpricing rate. This is because financial background allows board secretaries to explain and disclose financial information from a more professional perspective, which also proves hypothesis $\mathrm{H} 1$. In model 2 , the coefficient of experienced equals to -0.1017 and present negative significant correlation with IPO underpricing rate on level of $5 \%$, suggesting board secretaries with experiences working as board secretary in other companies can decrease IPO underpricing rate. This is because that board secretaries with related working experience better understand IPO procedure, more familiarize relative laws and regulations as well as related requirements of information disclosure, and appears to be more sensitive to relative policies, which also proves the hypothesis $\mathrm{H} 2$.

Besides, other several controlled variables presents significant relations with IPO underpricing rate: the higher the subscription rate is, the more IPO-bound companies the month before, the longer the founding time of the company, the larger the IPO scale is, the lower the IPO underpricing rate will be [9] [32] [33] [34] [35]; the higher the market return on the day and the ROE are, the higher the IPO underpricing rate will be [9].

\section{Robust Test}

Considering the influence of market return on IPO underpricing, adopting methods proposed by Huang Jun [36] and Chen Gongmeng [37], in which adjusted underpricing rate has been taken as explained variables. The result has been shown in Table 5. Adjusted IPO underpricing rate $=$ (closing price on first-day of IPO)/issue price-market return on the day. As Table 5 shown, in model (1), the coefficient of experienced equals to -0.0669 and presents negative significant relations on level of $5 \%$, which robustly supports the conclusion that board secretaries with financial background can decrease IPO underpricing rate. In model 2 , the coefficient of experienced equals to -0.1028 and present negative significant correlation with IPO underpricing rate on level of $5 \%$, robustly supporting the conclusion that board secretaries with experiences working as board secretary in other companies can decrease IPO underpricing rate. To control "Hot Issue", adding Hot Issue variable, the average IPO underpricing rate on the day in the month before IPO, may be appropriate [32]. As Table 6 shown, In model (1) and (2), the coefficient of finance is -0.0660 and the coefficient of experienced is -0.1028 , which also robustly support $\mathrm{H} 1$ and $\mathrm{H} 2$. 
Table 4. Board secretary's personal background and IPO underpricing.

\begin{tabular}{|c|c|c|}
\hline VARIABLES & (1) & (2) \\
\hline \multirow[t]{2}{*}{ finance } & $-0.0670^{\star \star}$ & \\
\hline & {$[0.0235]$} & \\
\hline \multirow[t]{2}{*}{ experienced } & & $-0.1017^{\star *}$ \\
\hline & & {$[0.0186]$} \\
\hline \multirow[t]{2}{*}{ edu } & 0.0251 & 0.0337 \\
\hline & [0.3589] & {$[0.2246]$} \\
\hline \multirow[t]{2}{*}{ gender } & -0.0066 & -0.0024 \\
\hline & {$[0.8322]$} & [0.9388] \\
\hline \multirow[t]{2}{*}{ lnage } & 0.0399 & 0.0420 \\
\hline & {$[0.6351]$} & {$[0.6171]$} \\
\hline \multirow[t]{2}{*}{ subscription } & $-0.0488^{\star * *}$ & $-0.0498^{* * *}$ \\
\hline & {$[0.0005]$} & {$[0.0004]$} \\
\hline \multirow[t]{2}{*}{ lnwage } & 0.0085 & 0.0070 \\
\hline & [0.7185] & {$[0.7668]$} \\
\hline \multirow[t]{2}{*}{ lag } & -0.0034 & -0.0155 \\
\hline & {$[0.9540]$} & {$[0.7922]$} \\
\hline \multirow[t]{2}{*}{ lag_number } & $-0.2873^{\star * \star}$ & $-0.3025^{\star * *}$ \\
\hline & {$[0.0000]$} & {$[0.0000]$} \\
\hline \multirow[t]{2}{*}{ market return } & $1.7612^{\star * *}$ & $1.8253^{* * *}$ \\
\hline & {$[0.0000]$} & {$[0.0000]$} \\
\hline \multirow[t]{2}{*}{ estyear } & $-0.0942^{\star \star}$ & $-0.0931^{\star *}$ \\
\hline & {$[0.0241]$} & {$[0.0257]$} \\
\hline \multirow[t]{2}{*}{ debt } & -0.0488 & -0.0136 \\
\hline & {$[0.7231]$} & {$[0.9221]$} \\
\hline \multirow[t]{2}{*}{ size } & 0.0783 & 0.0680 \\
\hline & {$[0.1110]$} & {$[0.1665]$} \\
\hline \multirow[t]{2}{*}{ independ director } & -0.2875 & -0.2826 \\
\hline & [0.2829] & [0.2909] \\
\hline \multirow[t]{2}{*}{ IPO size } & $-0.2025^{\star * \star}$ & $-0.1977^{* * *}$ \\
\hline & {$[0.0000]$} & {$[0.0000]$} \\
\hline \multirow[t]{2}{*}{ cpa firm rank } & 0.0295 & 0.0272 \\
\hline & [0.3296] & {$[0.3674]$} \\
\hline \multirow[t]{2}{*}{ growth } & -0.0197 & -0.0256 \\
\hline & [0.5157] & {$[0.4003]$} \\
\hline \multirow[t]{2}{*}{ ROA } & $0.5212^{*}$ & $0.5437^{\star}$ \\
\hline & {$[0.0763]$} & {$[0.0647]$} \\
\hline Year & Control & Control \\
\hline Industry & Control & Control \\
\hline \multirow[t]{2}{*}{ Constant } & $2.5613^{* * *}$ & $2.7450^{* * *}$ \\
\hline & {$[0.0010]$} & {$[0.0005]$} \\
\hline Observations & 352 & 352 \\
\hline Adjusted R-squared & 0.5027 & 0.5033 \\
\hline $\mathrm{F}$ & 10.59 & 10.61 \\
\hline
\end{tabular}

$* * *, * *, *$ represent significant correlation on levels of $1 \%, 5 \%$ and $10 \%$, respectively. 
Table 5. Robust test.

\begin{tabular}{|c|c|c|}
\hline VARIABLES & (1) & (2) \\
\hline \multirow[t]{2}{*}{ finance } & $-0.0669^{\star *}$ & \\
\hline & {$[0.0250]$} & \\
\hline \multirow[t]{2}{*}{ experienced } & & $-0.1028^{\star \star}$ \\
\hline & & {$[0.0183]$} \\
\hline \multirow[t]{2}{*}{ edu } & 0.0260 & 0.0348 \\
\hline & {$[0.3456]$} & {$[0.2143]$} \\
\hline \multirow[t]{2}{*}{ gender } & -0.0069 & -0.0027 \\
\hline & {$[0.8250]$} & {$[0.9326]$} \\
\hline \multirow[t]{2}{*}{ lnage } & 0.0354 & 0.0375 \\
\hline & {$[0.6761]$} & {$[0.6581]$} \\
\hline \multirow[t]{2}{*}{ subscription } & $-0.0486^{* * *}$ & $-0.0497^{\star * *}$ \\
\hline & {$[0.0006]$} & {$[0.0005]$} \\
\hline \multirow[t]{2}{*}{ lnwage } & 0.0097 & 0.0082 \\
\hline & {$[0.6824]$} & {$[0.7295]$} \\
\hline \multirow[t]{2}{*}{ lag } & -0.0052 & -0.0173 \\
\hline & {$[0.9305]$} & {$[0.7695]$} \\
\hline \multirow[t]{2}{*}{ lag_number } & $-0.2855^{\star * *}$ & $-0.3008^{\star * *}$ \\
\hline & {$[0.0000]$} & {$[0.0000]$} \\
\hline \multirow[t]{2}{*}{ Market return } & $0.7738^{* *}$ & $0.8389^{* *}$ \\
\hline & [0.0297] & {$[0.0191]$} \\
\hline \multirow[t]{2}{*}{ estyear } & $-0.0946^{\star *}$ & $-0.0935^{\star \star}$ \\
\hline & {$[0.0247]$} & {$[0.0262]$} \\
\hline \multirow[t]{2}{*}{ debt } & -0.0516 & -0.0158 \\
\hline & {$[0.7103]$} & {$[0.9100]$} \\
\hline \multirow[t]{2}{*}{ size } & 0.0804 & 0.0700 \\
\hline & [0.1049] & {$[0.1579]$} \\
\hline \multirow[t]{2}{*}{ Independent director } & -0.2878 & -0.2828 \\
\hline & {$[0.2863]$} & {$[0.2944]$} \\
\hline \multirow[t]{2}{*}{ Ipo size } & $-0.2047^{\star * *}$ & $-0.1999^{\star * *}$ \\
\hline & {$[0.0000]$} & {$[0.0000]$} \\
\hline \multirow[t]{2}{*}{ Cpa firm rank } & 0.0308 & 0.0285 \\
\hline & {$[0.3125]$} & {$[0.3486]$} \\
\hline \multirow[t]{2}{*}{ growth } & -0.0189 & -0.0249 \\
\hline & {$[0.5363]$} & {$[0.4177]$} \\
\hline \multirow[t]{2}{*}{ ROA } & $0.5161^{\star}$ & $0.5390^{*}$ \\
\hline & {$[0.0817]$} & {$[0.0693]$} \\
\hline Year & Control & Control \\
\hline Industry & Control & Control \\
\hline \multirow[t]{2}{*}{ Constant } & $2.5592^{\star * \star}$ & $2.7448^{\star * *}$ \\
\hline & {$[0.0011]$} & {$[0.0005]$} \\
\hline Observations & 352 & 352 \\
\hline Adjusted R-squared & 0.4607 & 0.4616 \\
\hline
\end{tabular}

$* * *, * *, *$ represent significant correlations on level of $1 \%, 5 \%$ and $10 \%$, respectively. 
Table 6. Robust test.

\begin{tabular}{|c|c|c|}
\hline VARIABLES & (1) & (2) \\
\hline \multirow{2}{*}{ finance } & $-0.0660^{\star \star}$ & \\
\hline & {$[0.0278]$} & \\
\hline \multirow[t]{2}{*}{ experienced } & & $-0.1028^{\star *}$ \\
\hline & & {$[0.0184]$} \\
\hline \multirow[t]{2}{*}{ edu } & 0.0250 & 0.0330 \\
\hline & [0.3698] & {$[0.2423]$} \\
\hline \multirow[t]{2}{*}{ gender } & -0.0065 & -0.0019 \\
\hline & {$[0.8351]$} & [0.9519] \\
\hline \multirow[t]{2}{*}{ lnage } & 0.0353 & 0.0371 \\
\hline & {$[0.6778]$} & {$[0.6618]$} \\
\hline \multirow[t]{2}{*}{ subscription } & $-0.0475^{* * *}$ & $-0.0477^{\star * *}$ \\
\hline & [0.0013] & {$[0.0012]$} \\
\hline \multirow[t]{2}{*}{ lnwage } & 0.0099 & 0.0085 \\
\hline & {$[0.6781]$} & {$[0.7208]$} \\
\hline \multirow[t]{2}{*}{ lag } & -0.0077 & -0.0218 \\
\hline & [0.8975] & {$[0.7157]$} \\
\hline \multirow[t]{2}{*}{ lagunderpricing } & 0.0230 & 0.0405 \\
\hline & {$[0.7713]$} & [0.6069] \\
\hline \multirow[t]{2}{*}{ lag_number } & $-0.2835^{\star * *}$ & $-0.2972^{\star * *}$ \\
\hline & {$[0.0001]$} & {$[0.0000]$} \\
\hline \multirow[t]{2}{*}{ market return } & $0.7942^{\star *}$ & $0.8758^{\star *}$ \\
\hline & [0.0289] & {$[0.0166]$} \\
\hline \multirow[t]{2}{*}{ estyear } & $-0.0949^{\star *}$ & $-0.0941^{* *}$ \\
\hline & {$[0.0245]$} & {$[0.0255]$} \\
\hline \multirow[t]{2}{*}{ debt } & -0.0548 & -0.0212 \\
\hline & [0.6945] & {$[0.8805]$} \\
\hline \multirow[t]{2}{*}{ size } & 0.0813 & 0.0717 \\
\hline & {$[0.1021]$} & {$[0.1494]$} \\
\hline \multirow[t]{2}{*}{ independ director } & -0.2947 & -0.2948 \\
\hline & {$[0.2776]$} & {$[0.2768]$} \\
\hline \multirow[t]{2}{*}{ IPO size } & $-0.2077^{\star * *}$ & $-0.2051^{* * *}$ \\
\hline & {$[0.0000]$} & {$[0.0000]$} \\
\hline \multirow[t]{2}{*}{ cpa firm rank } & 0.0306 & 0.0282 \\
\hline & {$[0.3164]$} & {$[0.3543]$} \\
\hline \multirow[t]{2}{*}{ growth } & -0.0185 & -0.0242 \\
\hline & {$[0.5457]$} & {$[0.4312]$} \\
\hline \multirow[t]{2}{*}{ ROA } & $0.5142^{*}$ & $0.5362^{\star}$ \\
\hline & {$[0.0834]$} & {$[0.0711]$} \\
\hline Year & Control & Control \\
\hline Industry & Control & Control \\
\hline \multirow[t]{2}{*}{ Constant } & $2.5670^{\star * *}$ & $2.7585^{* * *}$ \\
\hline & {$[0.0011]$} & {$[0.0005]$} \\
\hline Observations & 352 & 352 \\
\hline Adjusted R-squared & 0.4591 & 0.4603 \\
\hline $\mathrm{F}$ & 8.840 & 8.879 \\
\hline
\end{tabular}

$* * *, * *, *$ represent significant correlations on level of $1 \%, 5 \%$ and $10 \%$, respectively. 


\section{Conclusion}

Driven by information, the capital market will necessarily be influenced by the quality of information disclosed by the board secretary that serves as the key "bridge" linking the issuing company and the capital market. Information asymmetry has seriously restricted investors' understanding enterprises' status, development perspective, potential risks and so on, thus, it appears to be more essential for the company to disclose related information to allow investors to provide reasonable quotations during pricing inquiring. Board secretary is playing an irreplaceable role in information disclosure during enterprises IPO, which, though, has received little attention from academic circle. This paper is to study the influence of background of board secretary on IPO underpricing, the result of which shows that board secretaries with financial background or experiences working as board secretary in other companies can decrease enterprise's IPO underpricing rate. Based on the research, conclusion has been drawn to provide reference for enterprises' recruitment, currently occupation, stock-based incentives and so on. Meanwhile, supervision on Chinese GEM listed companies' information disclosure should also be enhanced to reduce information asymmetry, ensure reasonable quotation of new issue thus to promote the healthy development of capital market.

\section{References}

[1] Hambrick, D. and Mason, P. (1984) Upper Echelons: The Organization as a Reflection of Its Managers. Academy Management Review, 9, 193-206

[2] Gao, Q. and Wu, L.N. (2008) Can Board Secretary Holding a Current Post Improve the Quality of Information Disclosure?-Empirical Test of New Requirements Obtaining the Qualification of a Board Secretary in Proposed Revision of Listing Rules. Accounting Research, No. 1, 47-54.

http://qikan.cqvip.com/article/detail.aspx?id\%20=\%2026626866\&from $\% 20=\% 20 \mathrm{zk}$ search

[3] Mao, X.S., Wang, B., Lin, C.Q. and Wang, N. (2013) Information Provider and Efficiency of Capital Market. Economy Research, No. 10, 69-81.

http://istic.wanfangdata.com.cn/Search/Detail?db=zw_qk\&uniqueId=012013120095 7441

[4] Zhou, K.G., Li, T. and Zhang, Y. (2011) Board Secretary and Quality of Information Disclosure. Journal of Financial Research, No. 7, 167-181.

http://qikan.cqvip.com/article/detail.aspx?id=38531457\&from=zk_search

[5] Zhai, G.Y., Wu, L.C. and Kang, D.P. (2014) Does Chinese Listed Banks' Board Secretary Reduce the Quality of Information Disclosure?-Based on Empirical Analysis of Quarterly Data from 2007 to 2012. Economic Review, No. 02, 127-138. http://qikan.cqvip.com/article/detail.aspx?id=48769524\&from=zk_search

[6] Gao, F.L. and Wang, Z.Q. (2015) Research on Effect of Board Secretary's Social Capital on Quality of Information Disclosure. Nankai Business Review, No. 4, 60-71.

http://qikan.cqvip.com/article/detail.aspx?id=665935966\&from=writer_article

[7] Lin, C.Q., Mao, X.S. and Liu, K.X. (2016) Relation between Gender of Board Secretary and Quality of Information Disclosure-Empirical Evidence from Shanghai and Shenzhen a Stock Markets. Journal of Financial Research, No. 9, 193-206. 
$\underline{\text { http://istic.wanfangdata.com.cn/Search/Detail?db=zw_qk\&uniqueId=012016120106 }}$ $\underline{5924}$

[8] Akerlof, G.A. (1984) The Market for "lemon": Quality Uncertainty and the Market Mechanism. Quaterly Journal of Economics, 84, 488-500.

https://doi.org/10.2307/1879431

[9] Kevin, R. (1986) Why New Issues are Underpriced. Journal of Financial Economics, 15, 187-212. https://doi.org/10.1016/0304-405X(86)90054-1

[10] Beatty, R.P. and Ritter, J.R. (1986) Investment Banking, Reputation and the Underpricing of Initial Public Offerings. Journal of Financial Economics, 15, 213-232. https://doi.org/10.1016/0304-405X(86)90055-3

[11] Jiang, F.X. and Huang, J.C. (2013) Relations between Financial Experiences of CEO and Capital Structure Decision. Accounting Research, No. 5, 27-34. http://qikan.cqvip.com/article/detail.aspx?id=46199200\&from=zk_search

[12] Hitt, M. and Tyler, B. (1991) Strategic Decision Models: Integrating Different Perspectives. Strategic Management Journal, 12, 327-351. https://doi.org/10.1002/smj.4250120502

[13] Waller, M., Huber, G. and Glick, W. (1995) Functional Background as a Determinant of Executives' Selective Perception. Academy of Management Journal, 38, 943-974. https://doi.org/10.2307/256616

[14] Jiang, F.X., Shi, B.B. and Ma, Y.B. (2016) Relations between Information Publishers' Financial Experiences and Enterprises' Financing Constraints. Economy Research, No. 6, 83-97.

http://istic.wanfangdata.com.cn/Search/Detail?db=zw_qk\&uniqueId=012016090022 $\underline{0445}$

[15] Custódio, C. and Metzger, D. (2014) Financial Expert CEOs: CEO’s Work Experience and Firm's Financial Policies. Journal of Financial Economics, No. 1, 125-154. https://doi.org/10.1016/j.jfineco.2014.06.002

[16] Huang, Q., Jiang, F., Lie, E. and Yang, K. (2014) The Role of Investment Banker Directors in M \& A. Journal of Financial Economics, 112, 269-286.

https://doi.org/10.1016/j.jfineco.2014.02.003

[17] Jiang, F., Yin, Z., Su, F. and Huang, L. (2009) Relations between Managers' Background Characteristics and Enterprises' Over-Investment. Management World, No. $1,130-139$.

http://qikan.cqvip.com/article/detail.aspx?id=29298701\&from=zk_search

[18] Liu, J. and Zhang, L. (2014) Top Management's Working Experience of Auditors and Relationship on Accrual-Based and Real Earnings Management. Auditing Research, No. 4, 104-112.

http://qikan.cqvip.com/article/detail.aspx?id=661607910\&from=zk_search

[19] Wu, Y., Wu, S., Zhang, Q. and Wei, Z. (2016) Whether Board Secretary's Professional Background Influences IPO Process? Finance Research, No. 2, 11-24. http://qikan.cqvip.com/article/detail.aspx?id=67878974504849544850484850\&from =zk_search

[20] Liu, M. and Zhao, X. (2014) Cause of "Professional Board Secretary": Profit Seeking or Short Slab of Institutions? Management World, No. 4, 183-185. http://qikan.cqvip.com/article/detail.aspx?id=49169504\&from=zk_search

[21] Zhang, H. and Cui, X. (2009) IRM, Corporate Value and Investor Protection: An Empirical Study Based on the Appraisement Result of Top Secretaries of Directorate. Finance and Trade Research, No. 4, 138-144. http://qikan.cqvip.com/article/detail.aspx?id=31222359\&from=zk_search

[22] Jiang, F., Shi, B. and Ma, Y. (2016) Relation between Board Secretary's Financial 
Experiences and Content of Earning Information. Management World, No. 9, 161-173.

http://qikan.cqvip.com/article/detail.aspx?id=669977064\&from=zk_search

[23] Ibbotson, R.G. (1975) Price Performance of Common Stock New Issues. Journal of Financial Economics, No. 2, 235-272. https://doi.org/10.1016/0304-405X(75)90015-X

[24] Ritter, J.R. (1984) The Hot Issue Market of 1980. Journal of Business, 57, 215-240. https://doi.org/10.1086/296260

[25] Leone, A., Rock, S. and Willenborg, M. (2007) Disclosure of Intended Use of Proceeds and under Pricing in Initial Public Offerings. Journal of Accounting Research, 45, 111-153. https://doi.org/10.1111/j.1475-679X.2007.00229.x

[26] Chen, G. and Gao, N. (2000) Degree and Cause of Underpricing in Chinese IPOs Market. Journal of Financial Research, 8, 1-12. http://qikan.cqvip.com/article/detail.aspx?id=4367344\&from=zk_search

[27] Jing, C. and Carol, P. (2005) Short-Run Underpricing and Its Characteristics in Chinese Initial Public Offering (IPO) Markets. Research in International Business \& Finance, 19, 71-93. https://doi.org/10.1016/j.ribaf.2004.10.004

[28] Liu, Z., Zheng, K. and He, Y. (2011) Did First Stage of Inquiry System Work? Journal of Financial Research, 4, 158-173.

http://qikan.cqvip.com/article/detail.aspx?id=37447246\&from=zk_search

[29] Weng, X., Wang, K. and Lv, C. (2014) Effect of Family Members' Participating in Management on IPO Underpricing Rate. Management World, No. 1, 156-166. http://qikan.cqvip.com/article/detail.aspx?id=48353540\&from=zk_search

[30] Xu, X., Xia, Y. and Li, C. (2016) Enterprises' Signaling Effect among Independent R\&D, IPO Underpricing and Innovation Ability. Management of Economy, 38, 71-85

http://istic.wanfangdata.com.cn/Search/Detail?db=zw_qk\&uniqueId=012016090021 9209

[31] Ritter, J.R. and Welch, I. (2002) Review of IPO Activity, Pricing, and Allocations. Journal of Finance, 57, 1795-1828. https://doi.org/10.1111/1540-6261.00478

[32] Liu, L., Xiao, L., Sherman, A.E. and Zhang, Y. (2009) Media Coverage and IPO Underpricing. AFA San Francisco Meetings Paper.

[33] Wang, C. and Wu, J. (2015) Media Tone, Investor Sentiment and IPO Pricing. Journal of Financial Research, No. 9, 174-189. http://qikan.cqvip.com/article/detail.aspx?id=666526431\&from=zk_search

[34] Carter, R., Dark, F. and Singh, A.K. (1998) Underwriter Reputation, Initial Returns, and the Long-Run Performance of IPO Stocks. The Journal of Finance, 53, 285-311. https://doi.org/10.1111/0022-1082.104624

[35] Yu, F. and Wang, C. (2012) State Ownership and IPO Underpricing-From Perspective of Government's Price Ceiling. Journal of Financial Research, No. 9, 155-167. http://qikan.cqvip.com/article/detail.aspx?id=43443712\&from=zk_search

[36] Huang, J. and Chen, X. (2013) Media Coverage and IPO Underpricing: Evidence from China's Growth Enterprise Markets. Journal of Management Sciences in China, 2, 83-94. http://qikan.cqvip.com/article/detail.aspx?id=44825118\&from=zk_search

[37] Chen, G., Yu, X. and Kou, X. (2011) Effects of Venture Capitalists Participation on Underpricing of IPOs of Chinese Capital Cooperation. Economy Research, 5, 74-85. http://istic.wanfangdata.com.cn/Search/Detail?db=zw_qk\&uniqueId=012011121448 4832 